\title{
THE EPIZOOTIC ULCERATIVE SYNDROME (EUS) AFFECTED WITH CHANNA STRIATUS CAUSED MICROBIAL FLORA INFECTION IN HASANPARTHY LAKE
}

\section{P. KOTESHWAR RAO*}

Department of Zoology Kakatiya University, Telangana, India

\begin{abstract}
The microbial flora infection of the Skin and Gills of infected murrel Channa striatus in Hasanparthy, Lake of Warangal region, Telangana, India was estimated quantitatively and qualitatively and the isolates were identified at their genus and species level. Total viable microbial count was measured as highest range in skin $25 \times 10^{3}$ to $34 \times 10^{3}$ CFU g-1 and medium range in gills $\left(11 \times 10^{3}\right.$ to $\left.34 \times 10^{3}\right)$ g-1 PCA (Plate Count Agar). In total 4 bacterial species were isolated and identified. Aeromonas hydrophila, Staphylococcus aureus Pseudomonas aeruginosa, and Salmonella salmonicida colonies were the most predominant isolated and identified species. The purpose of this study is to isolate and identify the microflora of EUS infected C. striatus.

KEYWORDS: Skin, PCA, Aeromonas hydrophila
\end{abstract}

Received: Nov 20, 2020; Accepted: Dec 10, 2020; Published: Mar 12, 2021; Paper Id.: IJZRJUN20212

\section{INTRODUCTION}

The murrels are the air breathing fresh water fishes and are highly cost food in South- East Asian countries due to their tasty flavour, lower intra muscular spines. Murrels are very often affected by Epizootic Ulcerative Syndrome (EUS) and it is causes huge loss to the capture and culture sector. This is the major infectious agent of this fungal species of Aphanomyces invadans, (Mohan and Shankar, 1995) whereas the opportunistic bacterial infectious agent is Aeromonas hydrophila. In Telangana region the whole aquaculture is of fresh water carp culture and as this aquaculture is showing a promising income to the farmers more fresh water aquaculture farms are being started EUS (Epizootic Ulcerative Syndrome). Tail and fin rot, gill rot etc. In this aquatic environment microorganisms spread easily between habitats and hosts. (Amal S. Al-Sheraa, 2018).

Apart from bacterial and fungal diseases there are other diseases that include viral, Protozoan, Genetic and Environmental diseases. Aeromonas hydropila, Salmonella salmonicida, Pseudomonas fluorescens, Pseudomonas putrefaciens, Flexibacter columnar, Edwardsiella tarda, Vibrio alginolyticus, Streptococcus agalactiae, Lactococcus garvieae, Enterococcus faecalis, Yersinia ruckeri and V. parahaemolyticus are some of the bacterial species causes fin rot in adult fishes and fingerlings and also EUS (Govind et al., 2012; Sharma et al.,2012; Azizunnis 2013).

\section{MATERIAL AND METHODS}

The Hasanparthy lake farmers are rearing fingerlings of Indian murrels the healthy and diseased fish samples were collected from the freshwater lake during the period i.e., 2018- 2020. The EUS infected fishes were collected randomly. The diseased fishes exhibit clinical signs of the infections when selected. Fishes were alive when collected from the lake of Hasanparthy. 
After the thorough examination of external body surface and gills and the body cavity is carefully opened and targeted organs like skin and gills were isolated in to a sterile plastic container. Identification was confirmed by examination of stained smears and isolation of the organisms in an appropriate culture medium. Plate Count Agar (PCA) for Total Bacterial Count, Aeromonas isolation medium, Staphylococcus isolation medium and Pseudomonas isolation medium of Hi- media were used for isolation of bacteria. Smear was prepared by placing loop full of distilled water, emulsifying a little portion of material in the water with the loop and spreading the emulsion evenly over the centre of the slide. The slides was labelled with a diamond or greaseproof pencil and allowed to air dry. Before staining the smear was heat- fixed by passing the slide a few times through the upper part of a Bunsen flame. Smears were normally stained by Gram's Method.

Gram's stain reveals the presence of Gram- Positive or Gram- Negative organisms. The size and shape of bacteria was also noted and this, together with the consideration of the history and clinical signs of the disease indicates a likely identity. The collected fishes exhibited red ulcerations/ lesions on the body followed by reddening at the tips of paired and unpaired fins. In some fish samples there was loss of scales appearing reddish white patches with severe wound like appearance. This analysis and identification methodology was according to (Holt et al., 1994).

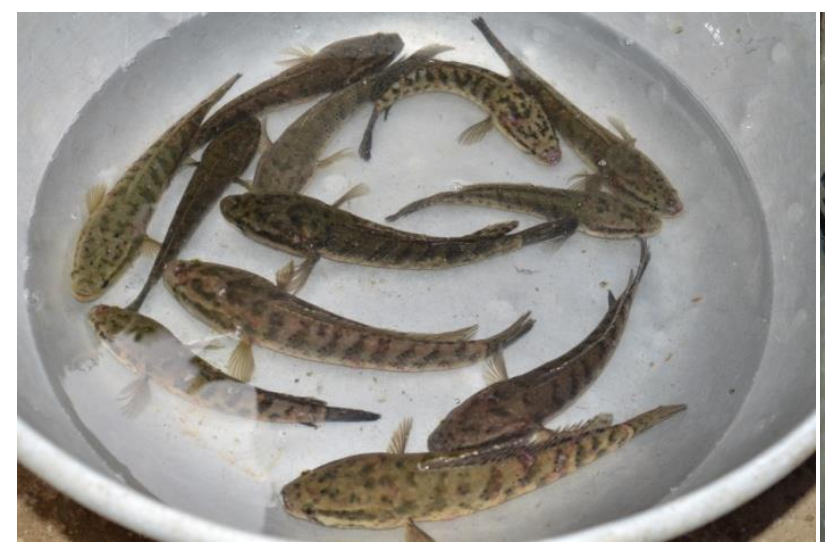

Figure 1: Healthy C. striatus

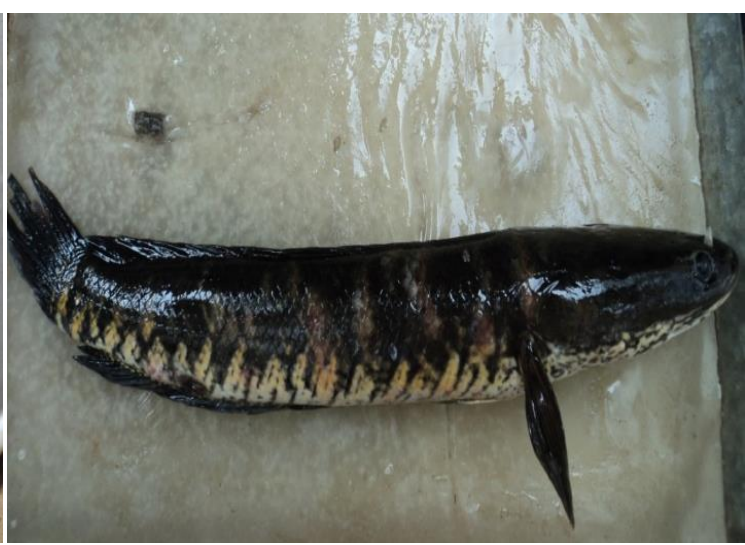

Figure 2: Infected $C$. striatus

\section{PROCEDURE}

\subsection{PREPARATION OF BACTERIAL CULTURE AND ISOLATION}

Tissue samples from the internal organs and the skin was streaked on to Nutrient Agar (NA) and Trypticase Soy Agar (TSA) and then incubated for $24-48 \mathrm{hrs}$, at $25 \pm 2^{\circ} \mathrm{C}$. The growing colonies were harvested in pure form and re incubated in Trypticase Soy Agar (TSA) for further identification.

TSA of $28.15 \mathrm{gm}$ was mixed in $500 \mathrm{ml}$ distilled water, heated to boiling to dissolve the medium completely. Cooled to $50^{\circ} \mathrm{c}$ and aseptically added dehydrated contents of one vial of Aeromanas selective supplement. Mixed well and dispensed for use as desired.

\section{RESULTS}

For bacteriological characterization, first the Total Plate Count on Plate count Agar Plate, Aeromonas hydrophila, Staphylococcus aureus Pseudomonas aeruginosa, Salmonella salmonicida colonies on respective agars were determined visually. They were yellow - greenish in colour on Aeromonas agar media and cream colored colonies on Pseudmonas 
agar media. (Plate I \& II). Further identification of bacteria species was done using morphological, physiological and the various biochemical tests.
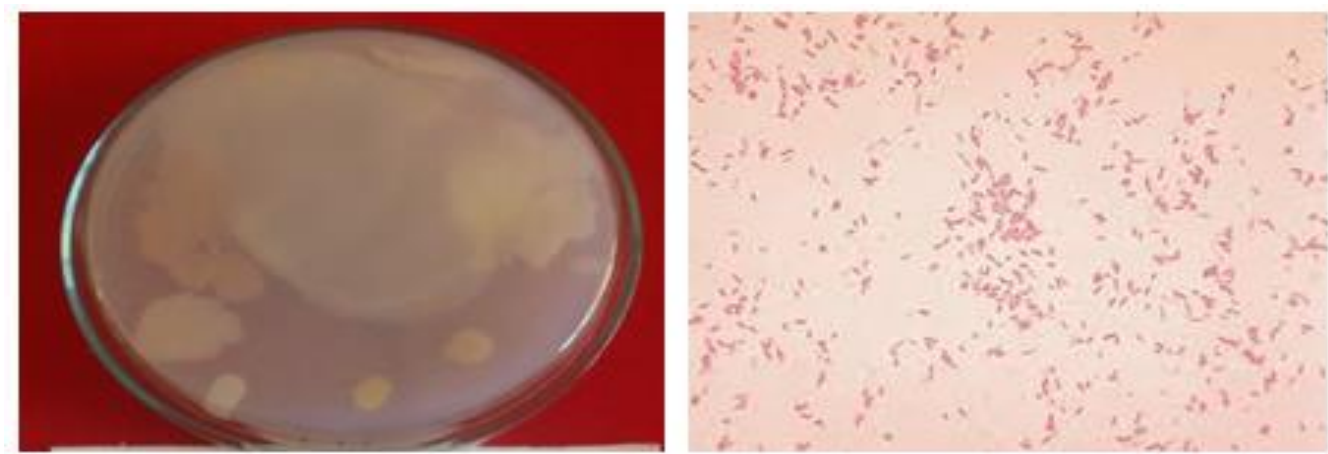

Aeromonas hydrophila Culture on Nutrient Agar (NA). (Gram - ve)
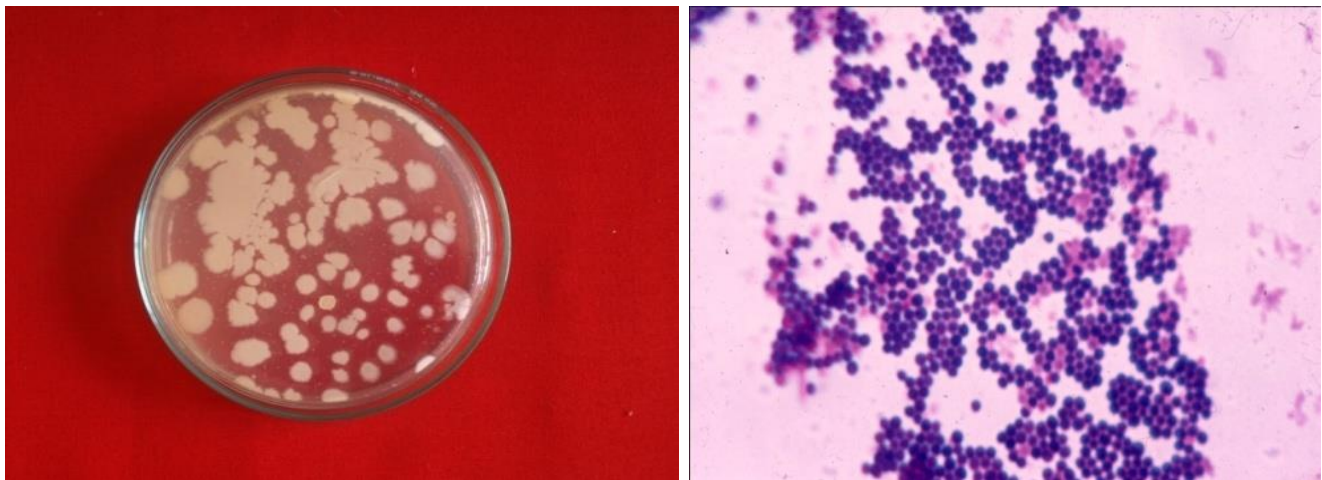

Staphylococcus aureus Culture on Nutrient Agar (NA). (Gram +ve)
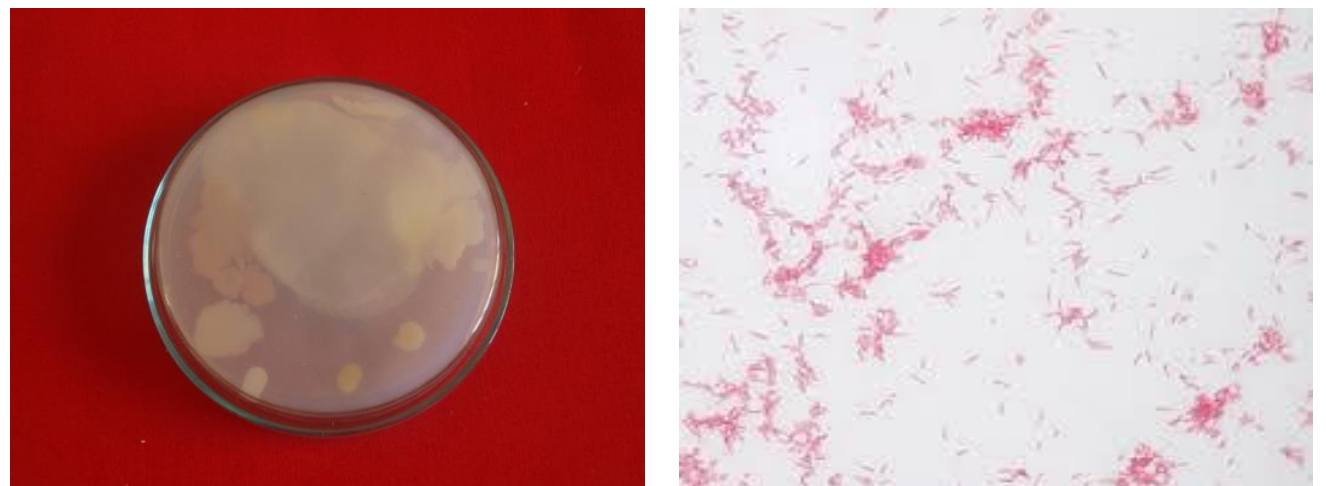

Pseudomonas aeruginosa Culture on Nutrient Agar (NA). (Gram -ve)
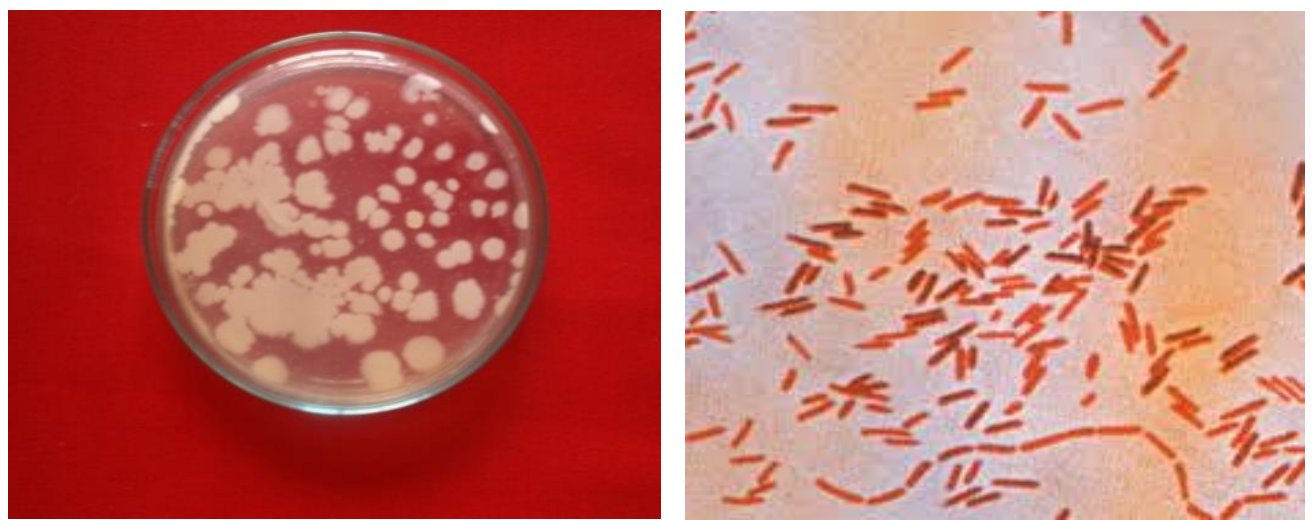

Salmonella salmonicida Culture on Nutrient Agar (NA). (Gram -ve) 
Table 1: Bacterial load in the Skin of Channa striatus from Hasanparthiy Lake (Phase - I\& II) 2018-19

\begin{tabular}{|c|c|c|c|c|c|c|}
\hline SI. No & Month & PCA & $\begin{array}{c}\text { Aeromonas } \\
\text { hydrophila }\end{array}$ & $\begin{array}{c}\text { Staphylococcus } \\
\text { aureus }\end{array}$ & $\begin{array}{c}\text { Pseudomonas } \\
\text { aeruginosa }\end{array}$ & $\begin{array}{c}\text { Salmonella } \\
\text { salmonicida }\end{array}$ \\
\hline 1 & June & $34 \times 10^{3}$ & 0 & 0 & 0 & 0 \\
\hline 2 & July & $25 \times 10^{3}$ & 0 & 0 & 0 & 0 \\
\hline 3 & Aug & $25 \times 10^{3}$ & 0 & 0 & 0 & 0 \\
\hline 4 & Sept & $25 \times 10^{3}$ & 0 & 0 & 0 & 0 \\
\hline 5 & Oct & $25 \times 10^{3}$ & $19 \times 10^{3}$ & $14 \times 10^{3}$ & $5 \times 10^{3}$ & $8 \times 10^{3}$ \\
\hline 6 & Nov & $25 \times 10^{3}$ & $17 \times 10^{3}$ & $12 \times 10^{3}$ & $7 \times 10^{3}$ & $5 \times 10^{3}$ \\
\hline Phase - II & \multicolumn{7}{|l|}{} \\
\hline 1 & Dec & $15 \times 10^{3}$ & $51 \times 10^{3}$ & $13 \times 10^{3}$ & $9 \times 10^{3}$ & 0 \\
\hline 2 & Jan & $11 \times 10^{3}$ & $43 \times 10^{3}$ & $5 \times 10^{3}$ & 0 & 0 \\
\hline 3 & Feb & $17 \times 10^{3}$ & 0 & 0 & 0 & $4 \times 10^{3}$ \\
\hline 4 & Mar & $13 \times 10^{3}$ & $28 \times 10^{3}$ & 0 & 0 & 0 \\
\hline 5 & Apr & $19 \times 10^{3}$ & 0 & 0 & 0 & 0 \\
\hline 6 & May & $22 \times 10^{3}$ & 0 & 0 & 0 & 0 \\
\hline
\end{tabular}

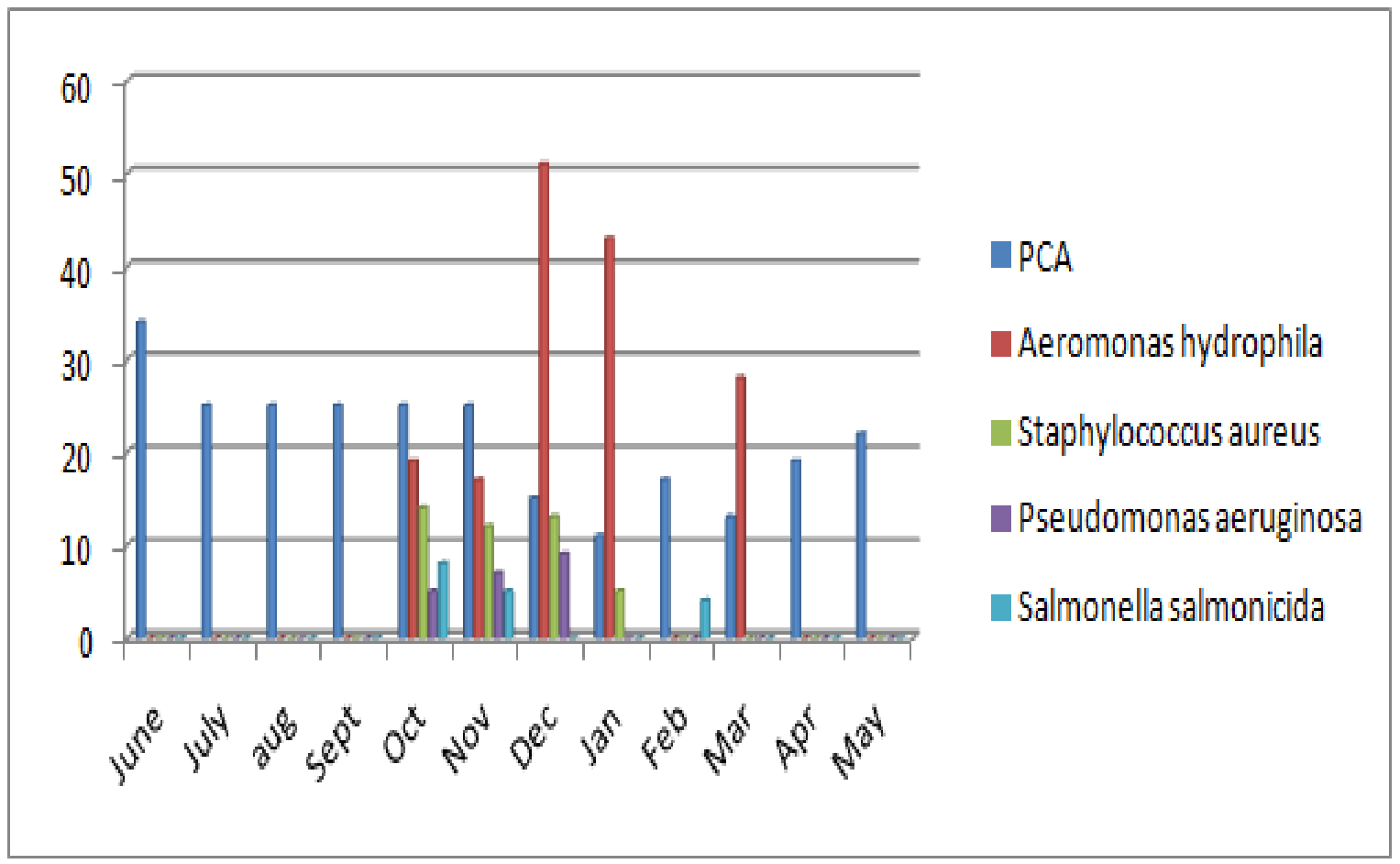

Figure 1: Bacterial load in the Skin of Channa striatus from Hasanparthy Lake (2018-19).

The total Plate count Agar in the Skin of Channa striatus found at Hasanparthy Lake were from $11 \times 10^{3}$ to $34 \times 10^{3}$ collectively in first and second phases during the year 2018-19. Aeromonas hydrophila was found from $17 \times 103$ to $51 \times 10^{3}$, Pseudomonas aeruginosa were from $5 \times 10^{3}$ to $9 \times 10^{3}$, Salmonella salmonicida were from $4 \times 10^{3}$ to $8 \times 10^{3}$ and Staphylococcus aureus $5 \times 10^{3}$ to $14 \times 10^{3}$. (Table 1 and Figure 1). 
Table 2: Bacterial load in the Gill of Channa striatus from Hasanparthy Lake (Phase - I\& II) 2018-19

\begin{tabular}{|c|c|c|c|c|c|c|}
\hline $\begin{array}{c}\text { Sl. } \\
\text { No }\end{array}$ & Month & PCA & $\begin{array}{c}\text { Aeromonas } \\
\text { hydrophila }\end{array}$ & $\begin{array}{c}\text { Staphylococcus } \\
\text { aureus }\end{array}$ & $\begin{array}{c}\text { Pseudomonas } \\
\text { aeruginosa }\end{array}$ & $\begin{array}{c}\text { Salmonella } \\
\text { salmonicida }\end{array}$ \\
\hline 1 & June & $34 \times 10^{3}$ & $25 \times 10^{3}$ & $25 \times 10^{3}$ & $25 \times 10^{3}$ & $25 \times 10^{3}$ \\
\hline 2 & July & $25 \times 10^{3}$ & 0 & $25 \times 10^{3}$ & $25 \times 10^{3}$ & $25 \times 10^{3}$ \\
\hline 3 & Aug & $25 \times 10^{3}$ & 0 & $25 \times 10^{3}$ & $25 \times 10^{3}$ & $25 \times 10^{3}$ \\
\hline 4 & Sept & $25 \times 10^{3}$ & 0 & $25 \times 10^{3}$ & $25 \times 10^{3}$ & $25 \times 10^{3}$ \\
\hline 5 & Oct & $25 \times 10^{3}$ & $43 \times 10^{3}$ & $25 \times 10^{3}$ & $25 \times 10^{3}$ & $25 \times 10^{3}$ \\
\hline 6 & Nov & $25 \times 10^{3}$ & $45 \times 10^{3}$ & $25 \times 10^{3}$ & $25 \times 10^{3}$ & $25 \times 10^{3}$ \\
\hline \multicolumn{7}{|c|}{ Phase - II } \\
\hline 1 & Dec & $25 \times 10^{3}$ & $51 \times 10^{3}$ & $25 \times 10^{3}$ & $25 \times 10^{3}$ & $25 \times 10^{3}$ \\
\hline 2 & Jan & $25 \times 10^{3}$ & $43 \times 10^{3}$ & $25 \times 10^{3}$ & $25 \times 10^{3}$ & $25 \times 10^{3}$ \\
\hline 3 & Feb & $25 \times 10^{3}$ & $38 \times 10^{3}$ & $25 \times 10^{3}$ & $25 \times 10^{3}$ & $25 \times 10^{3}$ \\
\hline 4 & Mar & $25 \times 10^{3}$ & $28 \times 10^{3}$ & $25 \times 10^{3}$ & $25 \times 10^{3}$ & $25 \times 10^{3}$ \\
\hline 5 & Apr & $25 \times 10^{3}$ & 0 & $25 \times 10^{3}$ & $25 \times 10^{3}$ & $25 \times 10^{3}$ \\
\hline 6 & May & $25 \times 10^{3}$ & 0 & $25 \times 10^{3}$ & $25 \times 10^{3}$ & $25 \times 10^{3}$ \\
\hline
\end{tabular}

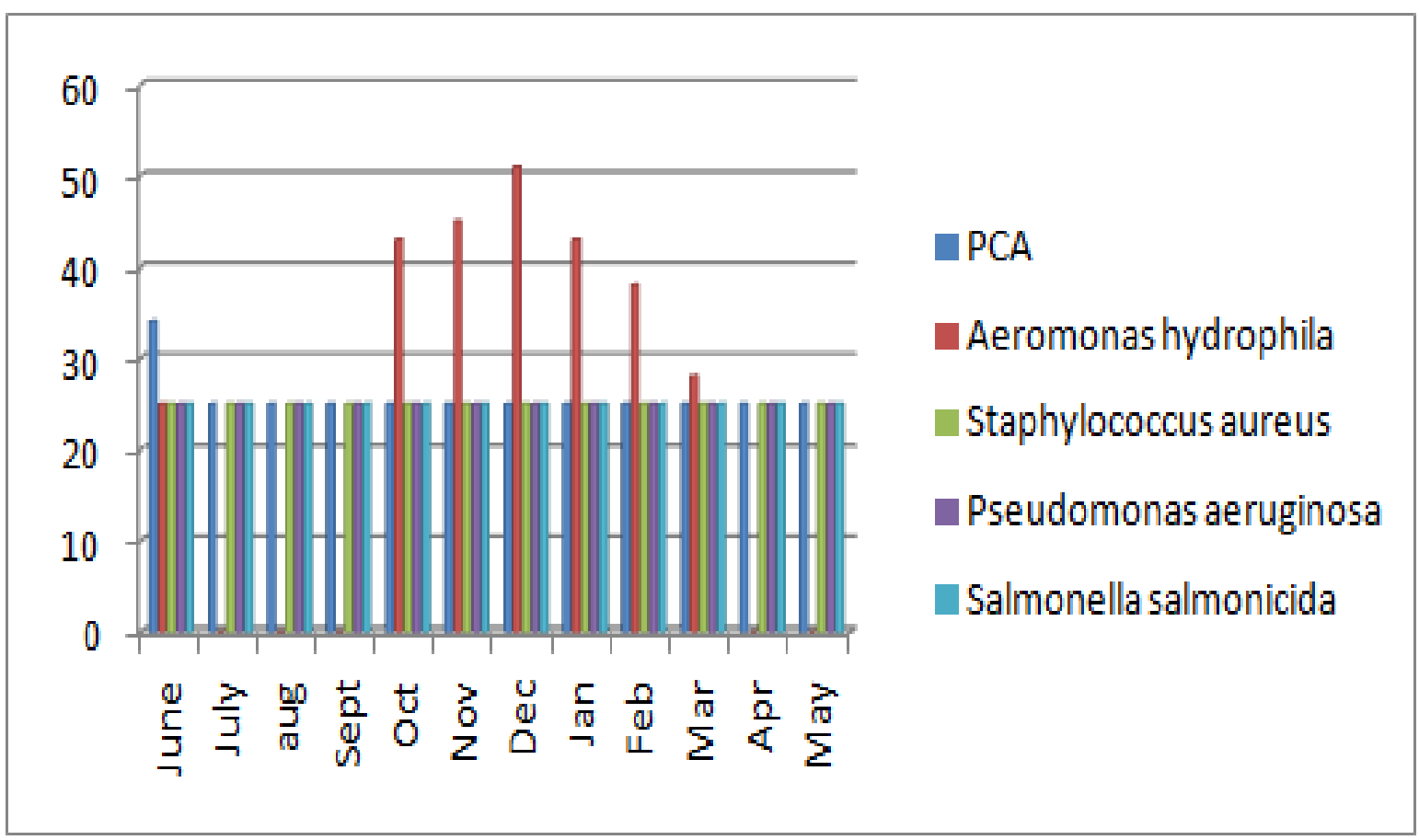

Figure 2: Bacterial load in the Gill of Channa striatus from Hasanparthy Lake (2018-19).

The total Plate count Agar in the gill of Channa striatus found at Hasanparthy Lake were from $25 \times 10^{3}$ to $34 \times 10^{3}$ collectively in first and second phases of the year 2019-20. Aeromonas hydrophila was found from $25 \times 10^{3}$ to $51 \times 10^{3}$, Pseudomonas aeruginosa were from $25 \times 10^{3}$ to $25 \times 10^{3}$, Salmonella salmonicida were from $25 \times 10^{3}$ to $25 \times 10^{3}$ and Staphylococcus aureus $25 \times 10^{3}$ to $25 \times 10^{3}$. (Table 2 and Figure 2). 


\section{DISCUSSION}

The quality of water is the first and most important limiting factor in existence of fish in any ecosystem. Aeromonads are probably the most commonly encountered bacterial pathogens of freshwater fish. Several species may be responsible for motile Aeromonas septicaemia in ornamental fish. (Natalia Walczak et, al., 2017).

Out breaks of bacterial diseases such as Aeromonas hydropila, Staphylococcus aureus, Pseudomonas aeruginosa and Salmonella and salmonicida were usually associated with changes in the environmental conditions. Stress factors, including overcrowding, low temperature, transfer of fish, low dissolved oxygen, poor nutritional status and parasitic damage of the epidermis, contribute to physiological changes and high susceptibility to infection. This was showed the occurrence of 4 species of bacteria (Aeromonas hydropila, Staphylococcus aureus, Pseudomonas aeruginosa and Salmonella salmonicida). In the Skin and Gills of freshwater C. striatus is causing red spot disease.

In Hasanparthy Lake the percentage positivity of Aeromonads in skin and gills were more in the second cycle than in the first cycle during the study period 2018-19 and 2019-20. The percentage of positivity of Staphylococcus aureus, Pseudomonas aeruginosa and Salmonella salmonicida also exhibited more during the second cycle in skin and gills than the first cycle during the study period. The water and oxygen parameters also favoured the multiplication of these bacteria.

\section{CONCLUSIONS}

The final study was clearly indicated concurrent infections of bacteria results in increasing the mortality. The infections of these bacteria in different tissues like skin and gills resulted in clinical symptoms. Fins and tails also observed during the present study. Factors like water quality also play a role in the infection of diseases. Poor dissolved oxygen, increased levels of gases such as ammonia and nitrite are the contributory factors for the escalation of mortality rate that finally resulted in less realization of seed from the cultured lakes in Warangal district, Telangana state, India. Overcrowding the culture lakes, erratic feed regime, poor husbandry practices do supplement onset of diseases.

\section{ACKNOWLEDGEMENT}

Author thanks to Prof. G. Benarjee Fisheries laboratory, Department of Zoology, Kakatiya University, Warangal inspiration and providing necessary facilities for this work.

\section{CONFLICT OF INTEREST}

There is no conflict of interest

\section{SOURCE OF FUNDING}

There is no external funding agency.

\section{REFERENCES}

1. Al-Sheraa, J Aquac Res Development 2018, 9:4 DOI: 10.4172/2155-9546.1000531

2. Azizunnisa, 2013. Some studies on the fish seed farms of Indian major carps in east Godavari district, Andhra Pradesh, India. Ph.D. Thesis, Fisheries Development Officer State Institute of Fisheries Technology. Kakinada, Visakhapatnam, Andhra University. 
3. Balasurya LKSW. 1987. Current fish disease problems in Srilanka in fish quarine and fish disease in South and Southeast Asia: 1986 update (ed. JR Arthur), p 36 -40. Special publication No.1. Asian Fisheries Society, Manila.

4. Dana P. 1987. Current fish problem in Indonesia. In: Fish quarantine and fish disease in South and Southeast Asia: 1986 update (ed. J.R. Arthur), pp 9-11. Special publication No. 1. Asian Fisheries Society, Manila.

5. Govind Pandey, S. Madhuri and A. K. Mandloi. 2012. "Medicinal plants useful in fish diseases." Pl. Arch 12.1: 1-4.

6. Lio-Po GD, Albright LJ and Alapide-Tendencia EV. 1992. Aeromonas hydropilain the epizootic ulcerative syndrome (EUS) of Snakehead, Ophicephalus striatus and Catfish, Clarias batrachus: quantitative estimation in natural infection and experimental induction of dermomuscular necrotic lesion. In Diseases in Asian Aquaculture Vol. II, Ed. Shariff M, Arthur JR and Subasinghe RP. 461-474. Manila, Philippines: Fish Health Section, Asian Fisheries Society.

7. Natalia Walczak, Krzyszt of Puk, Leszek Guz. 2017. J Vet Res 61, 445-449.

8. Roberts, R.J. Campbell B. and McRae.I.H. 1994. Proceedings on the ODA regional seminar on epizootic ulcerative syndrome.Aquatic Animal Health Research Institute, Bangkok, Thailand.

9. Sharma and Madhuri. 2012."Overviews of the treatment and control of common fish diseases."

10. Srivastara, R.C. 2009. Fish Mycopathology, Today and Tomorrow's printers and publishers New Dehli, India. 103. pp.

11. Willoughby, L. G. 1994. Fungi and Fish Diseases. Pisces Press, Stirling. UK. Pp, 57. 

